\title{
FAKTOR-FAKTOR PENYEBAB VANDALISME SISWA DAN UPAYA PENANGGULANGANNYA
}

Oleh :

\author{
Reka Yanti ${ }^{1)}$, Alber Tigor Arifyanto ${ }^{2)}$, Abas Rudin ${ }^{3)}$ \\ 1) 2) 3) Jurusan Bimbingan dan Konseling \\ Fakultas Keguruan dan Ilmu Pendidikan, Universitas Halu Oleo \\ Email:rekayn148@gmail.com
}

\begin{abstract}
ABSTRAK
Penelitian ini bertujuan untuk mengetahui faktor-faktor penyebab vandalisme siswa dan upaya penanggulangannya di SMA Negeri 6 Kendari. Jenis penelitian adalah penelitian kualitatif. Subjek dalam penelitian ini adalah guru bimbingan dan konseling, kepala sekolah, wali kelas, dan siswa SMA Negeri 6 Kendari. Teknik pengumpulan data dalam penelitian ini adalah wawancara, observasi dan studi dokumentasi. Metode analisis data menggunakan metode analisis deskriptif kualitatif model Miles dan Huberman. Hasil Penelitian adalah faktor-faktor yang menjadi penyebab siswa melakukan vandalisme di SMA Negeri 6 Kendari adalah faktor internal yaitu krisis identitas, kontrol diri yang lemah dan munculnya rasa iseng di dalam diri siswa untuk mencoba melakukan vandalisme tersebut. Kemudian faktor eksternal yaitu faktor dari lingkungan keluarga, sekolah dan masyarakat. Upaya penanggulangannya dengan memberikan layanan informasi, tindakan kuratif dan tindakan represif.
\end{abstract}

Kata Kunci: Vandalisme

\section{FACTORS THAT CAUSE STUDENT VANDALISM AND ITS MANAGEMENT EFFORTS}

\begin{abstract}
This study aims to determine the factors that cause student vandalism and their prevention efforts in Kendari State Senior High School 6. This type of research is qualitative research. The subjects in this study were guidance and counseling teachers, principals, homerooms, and students of Kendari Senior High School 6. Data collection techniques in this study were interviews, observation and documentation studies. The method of data analysis uses the qualitative descriptive analysis method of Miles and Huberman models. The results of the study are the factors that cause students to vandalism in Kendari State Senior High School are internal factors, namely identity crisis, weak self control and the emergence of a sense of fad in students to try to do vandalism. Then external factors are factors from the family environment, school and society. Mitigation efforts by providing information services, curative actions and repressive actions.
\end{abstract}

Keywords: Vandalism 


\section{Pendahuluan}

Dalam proses belajar di sekolah, siswa diajarkan untuk mengembangkan kemampuan, potensi dan bakat-bakat yang ada pada dirinya baik fisik maupun psikis sehingga siswa dapat terhindar dari perilaku menyimpang. Akan tetapi dalam pelaksanaanya, siswa terkadang melakukan pelanggaran serta perilaku-perilaku menyimpang lainnya. Perilaku menyimpang oleh Soekanto (dalam Soetomo, 2015: 92) disebut kejahatan kalau dalam batas-batas tertentu dianggap sebagai fakta sosial yang "normal" atau suatu tindakan yang melanggar norma atau peraturan di dalam masyarakat. Perilaku menyimpang yang sering terjadi yaitu perilaku mencuri, tawuran, penyalahgunaan narkotika termasuk perilaku vandalisme.

Perilaku menyimpang yang banyak terjadi di SMA Negeri 6 Kendari yaitu perilaku vandalisme (perusakan). Berdasarkan penelitian di sekolah tersebut, perilaku vandalisme siswa semakin hari semakin meningkat, perlu dianalisis agar siswa dapat mengatasi perilaku tersebut dikarenakan sangat berdampak pada sarana dan prasana yang menganggu proses pembelajaran di sekolah. Berdasarkan hasil observasi yang peneliti lakukan di SMA Negeri 6 Kendari diperoleh informasi bahwa terdapat siswa kelas XI IPS 2 yang cukup dikenal di sekolah, mereka sering menunjukkan perilaku yang dilakukan oleh siswa itu sendiri seperti: coret-coret dinding, bangku, meja, baju, pintu rungan, buku paket yang dipinjamkan bahkan koseng di dalam ruangan mereka melakukan aksi coret-coret tersebut.

Perilaku vandalisme berdampak pada kenyamanan orang lain, perusakan lingkungan serta menganggu ketertiban, apabila perilaku vandalisme dibiarkan begitu saja dan tidak segera ditangani akan membuat aksi dari tindakan tersebut semakin bertambah banyak karena mereka berpikir tidak adanya punishment membuat mereka diterima di lingkungannya.

Laksono (dalam Suhardi, 2018: 23) mengatakan vandalisme umumnya yang ditemui adalah mencoret-coret dinding sekolah, meja, kursi, jembatan, halte bus, merusak fasilitas umum seperti telpon umum, bus, WC umum, dan taman. Sementara dalam Kamus Besar Bahasa Indonesia (2005), definisi vandalisme ialah perbuatan merusak dan menghancurkan hasil karya seni dan barang berharga lainnya (keindahan alam dan sebagainya).
Salah satu perilaku yang sangat sering dilakukan oleh siswa agar identitas serta keberadaan mereka diakui dengan melakukan berbagai macam tindakan yang justru menunjukkan hal-hal yang tidak baik adalah dengan cara melakukan aksi mencoret-coret properti milik sekolah seperti menulis nama-nama di dinding, meja, kursi dan tembok-tembok sekolah. Informasi ini didukung oleh buku catatan kasus siswa di sekolah bahwa banyak kasus yang ditangani guru Bimbingan dan Konseling (BK), Hal ini didukung pula dengan hasil wawancara yang dilakukan oleh peneliti dengan guru BK dan guru mata pelajaran bahwa ada siswa yang mengalami vandalisme di sekolah.

Aksi vandalisme dipengaruhi oleh beberapa faktor, menurut Taylor (1997) bahwa the result related to risk factors and socialdeviance suggest that the number of family risk factors was correlated withboth vandalism and major deviance. Artinya, bahwa hasil korelasi yang didapatkan terhadap faktor-faktor yang memengaruhi dalam terjadinya penyimpangan sosial menunjukkan bahwa faktor terbesar yang memengaruhi adalah dari keluarga dengan terjadinya vandalisme dan penyimpanganpenyimpangan pada umumnya. Faktor-faktor yang berkaitan dengan vandalisme di dalam sekolah yaitu faktor internal yang berkaitan dengan perasaan siswa seperti emosi, rasa ingin diakui akan identitas mereka serta kurangnya kasih sayang dan perhatian dari keluarga. Sedangkan berdasarkan faktor eksternal yang berkaitan dengan pengaruh teman sebaya, keluarga, masyarakat serta media massa.

Menghadapi berbagai masalah tersebut, tidak semua individu mampu mengatasi masalahnya sendiri dan tidak dapat dipungkiri jika dalam keadaan seperti itu siswa perlu mendapatkan bantuan dari orang lain. Untuk itu sekolah hendaknya memberikan bantuan kepada siswa untuk mengatasi masalah-masalah yang timbul dalam kegiatan belajar siswa. Upaya pemberian bantuan tersebut bukan hanya dari guru bimbingan dan konseling (BK) saja tetapi diperlukan pula upaya yang dilakukan oleh wali kelas, guru mata pelajaran dan kepala sekolah agar dapat mengatasi atau mengurangi perilaku vandalisme yang dialami oleh siswa.

Hal itu tentu tidak dapat diabaikan begitu saja, untuk mengetahui lebih dalam mengenai fakta dan kondisi yang menyebabkan siswa mengalami vandalisme. Untuk itu, peneliti 
berkeinginan mengetahui faktor-faktor apa saja yang menjadi penyebab siswa melakukan perilaku vandalisme serta upaya penanggulangannya yang dilakukan oleh pihak sekolah. Dari penelitian ini juga diharapkan mampu memberikan penaganan maupun solusi yang diambil dapat sesuai dan membuahkan hasil yang baik pada semua pihak. Hal ini mendorong peneliti untuk melakukan penelitian guna mengungkap berbagai penyebab perilaku vandalisme dalam sebuah penelitian dengan judul "Faktor-Faktor Penyebab Perilaku Vandalisme dan Upaya Penanggulangannya di SMA Negeri 6 Kendari”.

Tujuan penelitian ini adalah untuk mengetahui apa saja faktor-faktor penyebab perilaku vandalisme siswa dan upaya apa yang telah dilakukan untuk penanggulangannya di SMA Negeri 6 Kendari.

\section{Definisi vandalisme}

Lase (2003: 3) mengemukakan bahwa vandalisme merupakan tindakan atau perbuatan yang mengganggu atau merusak berbagai obyek fisik dan buatan, baik milik pribadi maupun fasilitas umum. Selanjutnya, Cohen (dalam Yavuz1, 2011) menjelaskan vandalisme sebagai penghancuran ilegal sifat orang lain dan merusak penampilan mereka.

Bruchman (dalam Simanjuntak, 2012: 15) mengungkapkan bahwa vandalisme adalah penodaan atau perusakan yang menarik perhatian, dan dilakukan sebagai ekspresi kemarahan, kretivitas atau keduanya sedangkan dalam Kamus Besar Bahasa Indonesia, kata vandalisme berasal dari kata dasar vandal yang berarti perusak, kemudian mendapat akhiran isme maka mengundang arti perbuatan merusak dan menghancurkan hasil karya seni dan barang-barang berharga lainnya.

\section{Dampak vandalisme}

Dampak buruk yang ditimbulkan oleh aksi vandalisme menurut Elnadi (2018 : 47) adalah:

1. Perusakan lingkungan, dari pengertian di atas kita mengetahui bahwa vandalisme adalah tindakan perusakan terhadap segala sesuatu yang indah atau terpuji.

2. Mengganggu ketertiban, tidak hanya rusaknya lingkungan, namun ketertiban juga akan terganggu akibat adanya ulah aksi vandalisme ini karena pada dasarnya remaja yang melekukan vandalisme akan melanggar tata tertib yang ada sehingga tujuan mereka untuk melakukan vandalisme pun tercapai.

3. Mengganggu kenyamanan orang lain, remaja yang berulah vandalisme tentunya akan menggangu kenyamanan orang lain.

\section{Faktor penyebab vandalisme}

Safitri (2012: 109) menjelaskan bahwa vandalisme disebabkan oleh empat faktor, yaitu faktor yang berasal dari teman sebaya, faktor yang berasal dari keluarga, faktor yang berasal dari media masa, dan faktor yang berasal dari lingkungan. Selanjutnya, Santrock (2007: 81) menyebutkan faktor-faktor penyebab kenakalan remaja (vandalisme), yaitu:

1. Krisis identitas: Perubahan biologis dan sosiologis pada diri siswa memungkinkan terjadinya dua bentuk integrasi.

2. Kontrol diri yang lemah: Siswa yang tidak bisa memelajari dan membedakan tingkah laku yang dapat diterima dengan yang tidak dapat diterima akan terseret pada perilaku 'nakal'. Begitupun bagi mereka yang telah mengetahui perbedaan dua tingkah laku tersebut, namun tidak bisa mengembangkan kontrol diri untuk bertingkah laku sesuai dengan pengetahuannya.

\section{Metode Penelitian}

Penelitian ini dilaksanakan di 2 SMA Negeri 6 Kendari pada tahun akademik 2018/ 2019. Jenis penelitian yang digunakan dalam penelitian ini adalah metode kualitatif dengan jenis studi kasus (case studies). Sugiyono (2014: 140), menjelaskan penelitian kualitatif adalah jenis penelitian yang temuan-temuannya tidak diperoleh melalui prosedur statistik atau bentuk hitungan lainnya dan bertujuan mengungkapkan gejala secara holistikkontekstual melalui pengumpulan data dari latar alami dengan memanfaatkan diri peneliti sebagai instrumen kunci. Studi Kasus (case studies) merupakan jenis penelitian kualitatif yang mendalam tentang individu, kelompok, institusi dan sebagainnya dalam waktu tertentu Sugiarto (2015: 12).

Informan dalam penelitian ini adalah siswa kelas XI IPS 2 SMA Negeri 6 Kendari. Peneliti memilih 2 informan yang pernah melakukan vandalisme dan 2 orang yang tidak pernah melakukan vandalisme. Informan selanjutnya adalah 1 orang guru BK, Kepala Sekolah dan Wali Kelas serta Guru Mata Pelajaran.

Penelitian ini menggunakan teknik pengumpulan wawancara, studi dokumentasi dan 
observasi. Data yang diperoleh akan dianalisis dengan metode analisis deskriptif kualitatif, yaitu penyajian data dalam bentuk tulisan, dan menerangkan apa adanya sesuai dengan data yang diperoleh dari hasil penelitian, langkah terakhinya adalah menarik kesimpulan.

Langkah-langkah analisis data kualitatif yang digunakan mengacu pada pendapat Miles \& Huberman (dalam Sugiyono, 2015: 337) yakni: 1) Pengumpulan Data, 2) Reduksi Data, 3) Penyajian Data dan 4) Menarik Kesimpulan atau Verifikasi Data

\section{Hasil Penelitian dan Pembahasan Hasil Penelitian}

1. Faktor penyebab vandalisme

a. Faktor internal

1) Krisis identitas

Hasil yang diperoleh dari informan bahwa salah satu masalah yang kerap muncul dalam relasi adalah krisis identitas, yang dimaksud yaitu rasa ingin diakui oleh orang-orang sekitarnya. Krisis identitas adalah salah satunya agar tercapainya identitas peran siswa dalam lingkungannya, kegagalan dalam mencapai integrasi tersebut akan melibatkan berbagai aspek peran identitas sehingga untuk mencapai identitas tersebut siswa lebih memilih melakukan vandalisme walaupun identitas tersebut negatif. Tidak bisa dipungkiri bahwa siswa merupakan individu yang aktualisasinya butuh diakui, manusia berusaha memenuhi kebutuhannya dalam aktualisasi diri di dalam lingkungannya. Sehingga siswa membutuhkan rasa diterima oleh orangorang di sekitar dalam lingkungannya, di rumah, di sekolah maupun di mana lingkungan dia hidup.

2) Kontrol diri lemah

Hasil yang diperoleh dari informan bahwa kontrol diri yang lemah yaitu perasaan yang susah dikendalikan merupakan keadaan yang menyebabkan gangguan pada diri seseorang, baik karena perasaan yang timbul terlalu kuat dan mampu mendorong perubahan suasana hati seseorang menjadi marah, mengamuk, benci, jengkel, kesal hati ketika terjadi sesuatu yang tidak menyenangkan atau bahkan perasaan saat bahagia atau senang sehingga siswa tersebut memberikan respon atau bertingkah laku terhadap stimulus yang ada. b. Faktor eksternal

1) Faktor lingkungan keluarga

Keluarga merupakan sumber utama atau lingkungan yang utama penyebab kenakalan remaja salah satunya yaitu vandalisme ini. Hal ini disebabkan karena anak itu hidup dan berkembang pertama kali dari pergaulan keluarga yaitu hubungan antara orang tua dengan anak, ayah dengan ibu dan hubungan anak dengan anggota keluarga lain yang tinggal bersama-sama. Faktor utama yang menyebabkan vandalisme siswa yaitu kehidupan keluarga yang tidak harmonis, kondisi keluarga yang tidak harmonis karena sering terjadi keributan serta perselisihan yang menyebabkan pertengkaran dan berakhir dengan perceraian (Brokenhome) sangat berpengaruh besar pada perkembangan anak apalagi anak yang memasuki rentang usia remaja dimana mereka membutuhkan perhatian dan dukungan dari orang-orang terdekat terutama orang tuanya.

2) Lingkungan sekolah

Hasil yang diperoleh dari informan bahwa vandalisme yang sering dilakukan oleh siswa di sekolah adalah penulisan identitas siswa, menggambar saat lagi bosan serta menuliskan identitas kelompok. Penulisan identitas kelompok tersebut disebabkan karena krisis identitas selain dari itu vandalisme juga dapat dipengaruhi oleh teman sebaya yang sering kali melakukan tindakan vandalisme tersebut, dalam perkumpulan kelompok siswa tersebut mereka tidak memunyai tujuan dan apabila berkumpul maka timbulah berbagai ide negatif termasuklah mencoret dan merusakkan harta benda awam.

Pernyataan tersebut sejalan dengan pendapat responden yang dilihat dari faktor lingkungan sekolah salah satu pemicu terjadinya vandalisme dikalangan siswa selain dari faktor pengaruh teman sebaya, kurangnya pengawasan dari pihak sekolah dalam mengatasi masalah-masalah dalam lingkungan siswa juga menyebabkan mereka melakukan tindakan vandalisme.

3) Lingkungan masyarakat

Sikap tidak peduli masyarakat turut menyebabkan masalah vandalisme semakin 
meningkat. Setiap individu dalam sebuah masyarakat memunyai peranan penting dalam membentuk komunitas yang sehat, malangnya sikap masyarakat yang acuh tak acuh membuat siswa semakin merasa bahwa tindakan vandalisme yang mereka lakukan merupakan hal yang wajar. Kerusakan harta benda awam yang berlaku di sekitaran mereka sudah tidak lagi menjadi masalah mereka dan ini menyebabkan siswa terus menerus melakukan kegiatan vandalisme.

2. Upaya penaggulangan vandalisme

a. Layanan informasi

Layanan informasi bertujuan untuk memberikan pemahaman dan pengetahuan kepada siswa mengenai berbagai hal yang diperlukan selama proses belajar dan pembelajaran di sekolah. Tindakan yang diberikan guru BK sebagai upaya pencegahan terhadap tindakan vandalisme yang sering terjadi di lingkungan sekolah yaitu dengan memberikan layanan informasi di mana dalam pemberian layanan tersebut guru $\mathrm{BK}$ memberikan pada saat apel pagi atau saat jam pelajaran kosong guru BK masuk untuk menyampaikan dampak dan hukuman yang akan diberikan apabila ada siswa yang kedapatan melakukan vandalisme.

\section{b. Tindakan kuratif}

Tindakan kuratif ini bertujuan untuk memberikan penyadaran akan kesalahankesalahan yang telah dilakukannya serta mampu memperbaiki kehidupannya, sehingga di kemudian hari tidak lagi mengulangi kesalahan tersebut.

Tindakan yang diberikan wali kelas sebagai upaya penyembuhan terhadap tindakan vandalisme yang sering terjadi di lingkungan sekolah yaitu dengan memberikan punishment yang sifatnya tidak menghukum akan tetapi mengajarkan siswa tersebut agar bisa menjadi orang yang beranggung jawab dengan apa yang telah dilakukannya sehingga mereka dapat berpikir dua kali untuk melakukan tindakan tersebut.

\section{c. Tindakan represif}

Tindakan represif bertujuan untuk memberikan tindakan kepada siswa yang telah melakukan pelanggaran berulang-ulang kali sehingga perlu adanya tindaklanjut dari pihak sekolah agar pelanggaran yang telah terjadi dapat dihentikan. Tindakan yang diberikan kepala sekolah sebagai upaya penyembuhan terhadap tindakan vandalisme yang sering terjadi di lingkungan sekolah yaitu dengan memberikan punishment yang bersifat menegaskan kepada siswa akan apa yang telah dilakukannya, apabila telah kedapatan berkalikali melakukan vandalisme akan dikembalikan kepada orang tuanya karena pihak sekolah telah memberikan berbagai upaya untuk menghentikan tindakan vandalismenya tetapi siswa tersebut tetap melakukannya.

\section{Pembahasan}

Faktor-faktor penyebab terjadinya vandalisme siswa-siswi di SMA Negeri 6 Kendari disebabkan oleh dua faktor yaitu internal dan eksternal. Faktor internal yang pertama krisis identitas, pada dasarnya siswa pada masa ini manusia yang mencari jati dirinya mereka ingin keberadaan mereka diakui dan bisa dimaklumi. Maslow (dalam Romadhony, 2015) mengatakan bahwa manusia berusaha memenuhi kebutuhannya dalam aktualisasi diri di dalam lingkungannya sehingga siswa melakukan segala tindakan demi mencari perhatian agar identitas dirinya dapat diterima oleh orang-orang sekitarnya serta demi mendapat pengakuan akan identitasnya.

Berdasarkan penemuan di lapangan sesuai dengan yang dikatakan oleh Maslow bahwa pada proses pencarian identitas diri, siswa sering kali melakukan segala tindakan yang menyebabkan identitas dirinya dapat diakui, sebagian siswa menunjukkan identitas dirinya secara positif namun tidak sedikit juga yang membentuk identitasnya dengan cara yang negatif seperti pada siswa yang melakukan vandalisme karena mereka tidak mampu memenuhi tuntutan yang dibebankan pada mereka sehingga lebih memilih untuk melakukan tindakan tersebut.

Faktor internal yang kedua yaitu faktor kontrol diri yang lemah, Yusuf (dalam Safitri 2012: 23) mengatakan kontrol diri adalah kemampuan untuk mengontrol tindakan atas impuls atau desakan yang mungkin berbahaya karena impuls tersebut bertentangan dengan norma atau standar masyrakat tempat dia tinggal. Kemampuan kontrol diri diperlukan oleh siswa untuk mengurangi kemungkinan terjebak atau terlibat pada perbuatan yang menyimpang, akan tetapi tidak semua siswa mampu mengontrol dirinya dengan baik ada siswa yang mampu 
mengontrol perasaanya dan ada pula siswa yang susah untuk mengontrol perasaan yang sedang ia rasakan hal tersebut terlihat pada siswa yang mengalami vandalisme dia lebih memilih untuk meluapkan perasannya atau bahkan membagikan apa yang ia rasakan kepada orang-orang yang melihatnya misalnya saat dia merasa bahagia atau jatuh cinta dia menuliskan kata-kata cinta kepada pasangannya dengan tujuan agar semua orang tahu bahwa dia sedang berbahagia. Selain dari krisis identitas dan kontrol diri lemah, yang menyebabkan terjadinya vandalisme pada siswa lainnya juga berupa rasa iseng yang tumbuh dalam dirinya sehingga menyebabkan dia melakukan tindakan vandalisme tersebut, vandalisme yang dilakukan oleh siswa ini semata-mata hanya untuk bermain dan untuk mendapatkan kesenangan semata.Selain itu munculnya rasa bosan membuat siswa melakukan vandalisme untuk menghilangkan rasa bosan dan kejenuhan tersebut sehingga siswa memilih untuk mencoret properti sekolah yang ada di dekat mereka.

Faktor eksternal pertama yang menyebabkan siswa melakukan vandalisme adalah faktor keluarga. Keluarga merupakan lembaga pertama dan utama dalam melakukan proses sosialisasi dan sivilisasi pribadi anak. Di tengah keluarga, anak belajar mengenal makna cinta kasih, simpati, loyalitas, ideologi, bimbingan dan pendidikan. Keluarga memberikan pengaruh menentukan pada pembentukan watak dan pribadi anak dan menjadi unit sosial terkecil yang memberikan fondasi primer bagi perkembangan anak. Baik buruknya struktur keluarga memberikan dampak baik atau buruknya perkembangan jiwa dan jasmani anak (Kartono, 2011: 120). Kondisi keluarga yang tidak harmonis karena sering terjadi keributan serta perselisihan yang menyebabkan pertengkaran dan berakhir dengan perceraian (brokenhome) sangat berpengaruh besar pada perkembangan anak apalagi anak yang memasuki rentang usia remaja di mana mereka membutuhkan perhatian dan dukungan dari orang-orang terdekat terutama orang tuanya, karena kurangnya perhatian dari orang tua menyebabkan siswa tersebut melakukan vandalisme untuk mencari perhatian dari orangorang sekitarnya. Pengawasan orang tua sangat penting dalam menentukan apakah siswa tersebut melakukan vandalisme atau tidak. Sependapat dengan penemuan di lapangan bahwa siswa yang melakukan vandalisme karena penyebab dari kondisi keluarga yang tidak harmonis, dari kondisi keluarga tersebut membuat perhatian mereka terhadap anak jadi berkurang sehingga siswa tersebut melakukan segala upaya untuk menarik perhatian dari orang tuanya.

Selain dari faktor keluarga, faktor dari lingkungan sekolah yaitu kurangnya pengawasan dari pihak sekolah serta pengaruh dari teman sebaya juga menyebabkan siswa melakukan tindakan vandalisme. Siswa pada umumnya selalu berkelompok mencari teman yang sepadan dan sepemikiran, siswa juga terkadang lebih banyak meluangkan waktu dengan teman sebaya sehingga memengaruhi sikap, minat dan tingkah laku mereka. Pengaruh rekan sebaya sangat penting dalam pergaulan siswa, siswa yang salah memilih rekan yang baik akan terikut ke dalam perilaku negatif yang dilakukan oleh temannya karena kebanyakan siswa yang melakukan tindakan vandalisme dilakukan secara berkelompok. Sarwono (dalam Safitri 2012: 36) menyebutkan bahwa seorang anak akan menjadi baik atau jahat tergantung dari pengalaman. Kalau anak mendapat pengalaman yang baik, maka anak tersebut akan menjadi baik, demikian sebaliknya. Sependapat dengan teori dari Sarwono bahwa anak yang memiliki pengalaman dan teman kelompok yang baik akan menjadi baik namun apabila sebaliknya akan cenderung mengikuti apa yang dilakukan oleh teman kelompoknya seperti yang ditemui di lapangan bahwasannya siswa yang melakukan vandalisme didorong dari pengaruh teman kelompoknya yang sering melakukan vandalisme sehingga anak tersebut mengikuti tindakan mereka.

Faktor yang terakhir adalah faktor dari lingkungan masyarakat yaitu sikap acuh tak acuh atau ketidakpedulian masyarakat kepada siswa yang melakukan vandalisme dapat membuat mereka merasa apa yang dilakukannya dapat diterima oleh lingkungan sekitar dan mereka memandang apa yang dilakukannya bukan perbuatan negatif karena kurangnya teguran dari pihak masyarakat setempat. Selain dari ketiga faktor eksternal tersebut, faktor dari media massa juga menjadi penyebab siswa melakukan vandalisme. Media massa memunyai pengaruh dan kesan yang amat kuat, paparan adegan-adegan negatif dari film atau rancangan dari barat yang memunyai unsur-unsur perlakuan ke arah vandalisme bisa saja memengaruhi siswa melakukan vandalisme. Golongan siswa pada masa ini lazimnya mudah meniru dan mengikuti hal-hal yang dilihat di sekeliling termasuk media massa, apa lagi tanpa bimbingan dan arahan yang sewajarnya. Siswa dapat melakukan vandalisme 
karena pernah melihat idola mereka dalam film tersebut melakukan coretan yang membuat mereka terlihat keren sehingga siswa melakukan vandalisme demi terlihat keren seperti idolanya tersebut.

Dari beberapa faktor yang dikemukakan oleh peneliti tersebut, sesuai dengan pendapat Santrock (2007: 81) yang menjelaskan setidaknya terdapat dua faktor internal yang menyebabkan siswa melakukan vandalisme yaitu 1). Krisis identitas demi memenuhi kebutuhan akan aktualisasi dirinya sehingga melakukan vandalisme, 2). Kontrol diri yang lemah karena kurangnya kemampuan siswa dalam mengontrol dirinya atau perasaan yang sedang dirasakan sehingga mereka memilih untuk melakukan vandalisme. Selain dari dua faktor internal yang dikemukakan oleh Santrock tersebut, peneliti menemukan faktor internal lain yang menyebabkan siswa melakukan vandalisme yaitu tumbuhnya rasa bosan dan iseng di dalam diri siswa sehingga mereka melakukan vandalisme.

Hasil penelitian ini sesuai pendapat Safitri (2012: 109) menjelaskan setidaknya terdapat tiga faktor ekternal yang menyebabkan siswa melakukan vandalisme yaitu 1). Lingkungan keluarga, Kehidupan keluarga yang hancur luluh baik dalam bentuk broken home maupun kurangnya perhatian orang tua kepada anaknya sehingga memberi dorongan yang kuat anak melakukan vandalisme. 2). Lingkungan sekolah, kehidupan di sekolah dengan segala keanekaragaman karakter siswa (termasuk yang negatif) ikut memengaruhi munculnya vandalisme pada siswa. 3). Lingkungan masyarakat, kehidupan lingkungan sehari-hari dengan keanekaragaman kondisi negatif serta kurangnya sikap peduli masyarakat akan memberi dukungan kuat dalam proses vandalisme siswa.

Jika ditinjau dari segi teori Cohen's yang mengatakan perilaku vandal itu umumnya tengah mengalami gangguan kejiwaan sebagai akibat kondisi sosial ekonomi yang tidak kondusif atau dapat juga diakibatkan oleh kurangnya perhatian orang-orang sekitar terutama keluarga. Setiap siswa berusaha memenuhi kebutuhannya dalam aktualisasi diri di dalam lingkungannya, sehingga siswa membutuhkan rasa diterima oleh orangorang di sekitarnya.

Upaya penanggulangan vandalisme di SMA Negeri 6 Kendari yaitu 1). Guru BK memberikan layanan informasi, menurut Winkel (dalam Tohirin 2007: 147) layanan informasi merupakan suatu layanan yang berupaya memenuhi kekurangan individu akan informasi yang mereka perlukan. Individu memerlukan berbagai informasi baik untuk keperluan kehidupannya sehari-hari, sekarang maupun untuk perencanaan kehidupannya ke depan. Individu bisa mengalami masalah dalam kehidupannya sehari-hari maupun kehidupannya di masa depan, akibat tidak mampu mengakses informasi. 2). Wali Kelas memberikan tindakan kuratif dengan tujuan untuk memberikan penyadaran akan kesalahan-kesalahan yang telah dilakukannya serta mampu memerbaiki kehidupannya, sehingga di kemudian hari tidak lagi mengulangi kesalahan tersebut. 3). Kepala Sekolah memberikan tindakan represif ini dapat bertujuan untuk memberikan tindakan kepada siswa yang telah melakukan pelanggaran berulangulang kali sehingga perlu adanya tindak lanjut dari pihak sekolah agar pelanggaran yang telah terjadi dapat dihentikan. Hal ini, sesuai dengan yang dikemukakan oleh Gunarsa (dalam Mumtahanah, 2015: 280) suatu usaha atau tindakan untuk menindas dan menahan kenakalan remaja sesering mungkin atau menghalagi timbulnya peristiwa yang lebih kuat".

\section{Kesimpulan dan Saran Kesimpulan}

Berdasarkan hasil analisis terhadap data penelitian, dapat disimpulkan bahwa faktor-faktor penyebab siswa melakukan vandalisme di SMA Negeri 6 Kendari yakni karena faktor internal yaitu krisis identitas, kontrol diri yang lemah, tumbuhnya rasa bosan dan rasa iseng pada siswa. Selanjutnya, faktor eksternal yang menyebabkan siswa melakukan vandalisme yaitu lingkungan keluarga, lingkungan sekolah, lingkungan masyarakat dan media massa. Upaya penanggulangan yang diberikan pihak sekolah kepada siswa yang mengalami vandalisme yaitu dari guru BK berupa pemberian layanan informasi, dari wali kelas berupa pemberian tindakan kuratif dan dari kepala sekolah dengan memberikan tindakan represif yaitu pemberian punishment apabila telah melewati batas toleransi dari peraturan yang berlaku.

\section{Saran}

Berdasarkan kesimpulan yang dikemukakan di atas, maka saran yang dapat peneliti berikan sehubungan dengan hasil penelitian ini antara lain: 1. Bagi kepala sekolah, agar memberikan pemahaman mengenai dampak dari perbuatan 
vandalisme dan mampu bekerja sama dengan seluruh personil sekolah dalam pengawasan siswa.

2. Bagi guru BK, ketika dihadapkan pada permasalahan vandalisme siswa, diharapkan dapat menindak lanjuti dan menerapkan layanan konseling kelompok untuk mengatasi perilaku vandalisme siswa.

3. Kepada Keluarga, diharapkan dapat berkolaborasi dengan guru-guru yang ada di sekolah guna melihat perkembangan anak dan mampu membentuk pola pikir yang baik terhadap para pelajar serta memberikan pengawasan dan perhatian terhadap perilaku anaknya di luar rumah.

4. Kepada siswa, agar menyadari bahwa tujuan utama ke sekolah adalah untuk menuntut ilmu. Karena itu hendaknya setiap pelajar harus menjaga setiap perilakunya baik di dalam lingkungan sekolah maupun di luar lingkungan sekolah.

\section{Daftar Pustaka}

Aysel Yavuzl. (2011). The Effects Of Locational Factors On Vandalism In The Seaside Parks. Scientific Research And Essays Vol. 6.

Amara. (2013). Hubungan Antara Konformitas Negatif Dengan Tindakan Vandalisme. Jurnal Pendidikan.

Ani, Safitri. (2012). Pengaruh Budaya Hedonism Terhadap Timbulnya Vandalisme Siswa. Jurnal Teknologi Pendidikan Vol 1 No 2.

Isran, Elnadi. (2018). Vandalisme Koleksi di Unit. Jurnal Ilmu Perpustakaan dan Informasi Vol.2/ No.1.

Lase. (2003). Karakteristik Vandalisme. Jurnal Psikologi.

Marlini. (2013). Faktor-faktor Penyebab Terjadinya Tindakan Vandalisme di Kantor Arsip Perpustakaan dan Dokumentasi Kota Padang. Jurnal Bimbingan dan Konseling.

Nurotun, Mumtahanah. (2015). Upaya Menanggulangi Kenakalan Remaja Secara Preventif, Refresif, Kuratif dan Rehabilitasi. Jurnal Studi Keislaman, Volume 5 No 2.
Santrock, J.W. (2007). Adolescene: Perkembangan Remaja. Jakarta: Erlangga.

Soetomo. (2015) Masalah Sosial dan Upaya Pemecahannya. Yoyakarta: Pustaka Pelajar.

Sukardi, Dewa Ketut. (2000). Pengantar Program Bimbingan dan Konseling di Sekolah. Jakarta: Rineka Cipta.

Sugiyono. (2014). Metode Penelitian Pendidikan Pendekatan Kuantitatif, Kualitatif dan R\&D. Bandung: Alfabeta.

Sugiyono. (2017). Metode Penelitian Kualitatif. Bandung: Alfabeta.

Sumadi. (2016). Metedologi Penelitian. Jakarta: PT Raja Grafindo Persada.

Tohirin. (2007). Bimbingan dan Konseling di Sekolah dan Madrasah. Jakarta: PT Raja Grafindo.

Dorothy L. Taylor, etc. (1997), Family Factors, Theft, Vandalism, and Major Deviance Among a Multiracial or Multiethnic Sample of Adolescent Girls". Journal Of Social Distress and The Homeless. Vol. 6, No. 1. Florida: University of Miami. 